\title{
HISTORICAL CHANGES IN THE LAND USE
} CONNECTED WITH APPROPRIATION OF AGRICULTURAL LAND CASE STUDY OF CADASTRAL AREAS DOLNÍ VĚSTONICE AND MODŘICE (CZECH REPUBLIC)

\author{
Jan Szturc ${ }^{1}$, Petr Karásek², Jana Podhrázská ${ }^{3}$
}

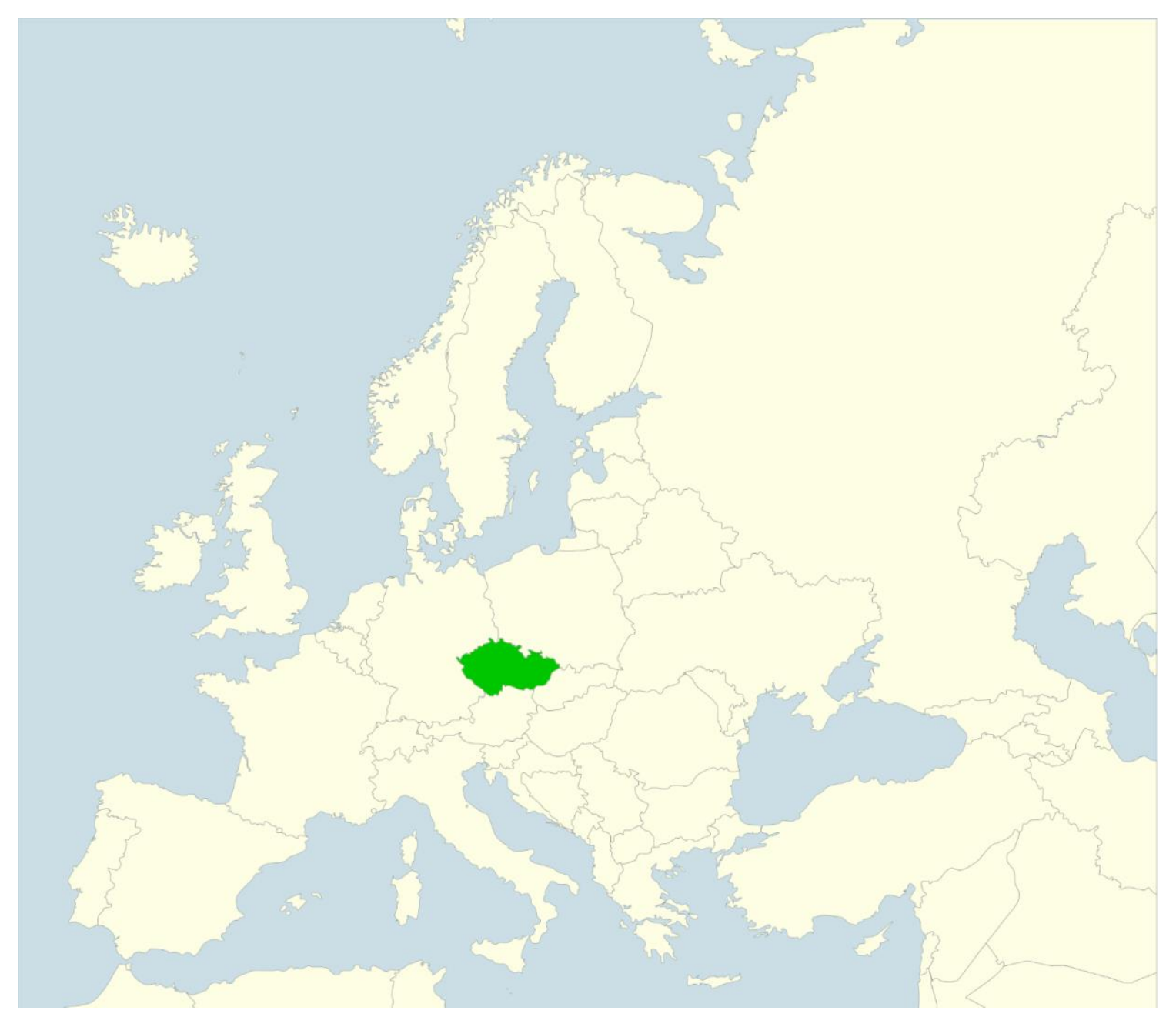

\footnotetext{
${ }^{1}$ Ing. Jan Szturc, Ph.D. student, Faculty of AgriSciences, Mendel University in Brno, Zemědělská 1, 61300 Brno, Czech Republic, e-mail: jan.szturc@seznam.cz

${ }^{2}$ Mgr. Petr Karásek, Research Institute for Soil and Water Conservation, v.v.i., Department of Land Consolidations and Landscape Use, Lidická 25/27, 60200 Brno, Czech Republic, e-mail: karasek.petr@vumop.cz

${ }^{3}$ Doc. Ing. Jana Podhrázská, PhD., Faculty of AgriSciences, Mendel University in Brno, Zemědělská 1, 61300 Brno, Czech Republic and Research Institute for Soil and Water Conservation, v.v.i., Department of Land Consolidations and Landscape Use, Lidická 25/27, 60200 Brno, Czech Republic, e-mail: jana.podhrazska@mendelu.cz
} 
Abstract: The article focuses on the issue of agricultural soil sealing in the Dolni Věstonice and Modríce cadastres (South Moravian Region). Available data and map resources were used for this purpose (historical and up-to-date). Data was processed using manual digitalisation which helped to generate the needed map output. The decrease in area of agricultural land is analysed in individual periods starting in the year 1824 (source of data stable cadastre - the first half of the $19^{\text {th }}$ century) until the present, and the sealing of different types of plots and soil kinds is assessed according to Evaluated Soil-Ecological Units (ESEU). In most cases, agricultural land sealing is associated with municipal expansion. To compare future development, potential (forthcoming) agricultural land sealing proposed within the valid landscape plans was also explored. Likewise, the overall price of sealed plots in both locations was calculated. The results show that there was a significant change in the use of both model territories between 1824 and the present. In Modrice, the area of the built-up area was changed from 16 ha (1824) to 409 ha (2016). The area of the site has expanded from $90 \%$ to agricultural land. The most significant change in this area is the development of builtup areas on agricultural land. In the model territory of Dolní Věstonice, the area of the built-up area increased from 16 ha (1824) to 48 ha (2016). The area of the site has expanded from $70 \%$ to agricultural land. Due to the construction of water reservoirs "Nové Mlýny", the area of water bodies increased by 569 ha (during the period 18242016). The water reservoirs occupy $65 \%$ of the cadastral area of Dolní Věstonice. The most significant change in landscape is the increase in water areas in Dolni Věstonice. Should this trend persist, an extensive reduction in agricultural soil and ensuing problems associated with sustainable agriculture, potentially also deficient food resources must be anticipated.

Key words: Soil sealing, Land use, degradation, ESEU, price of soil, urban sprawl

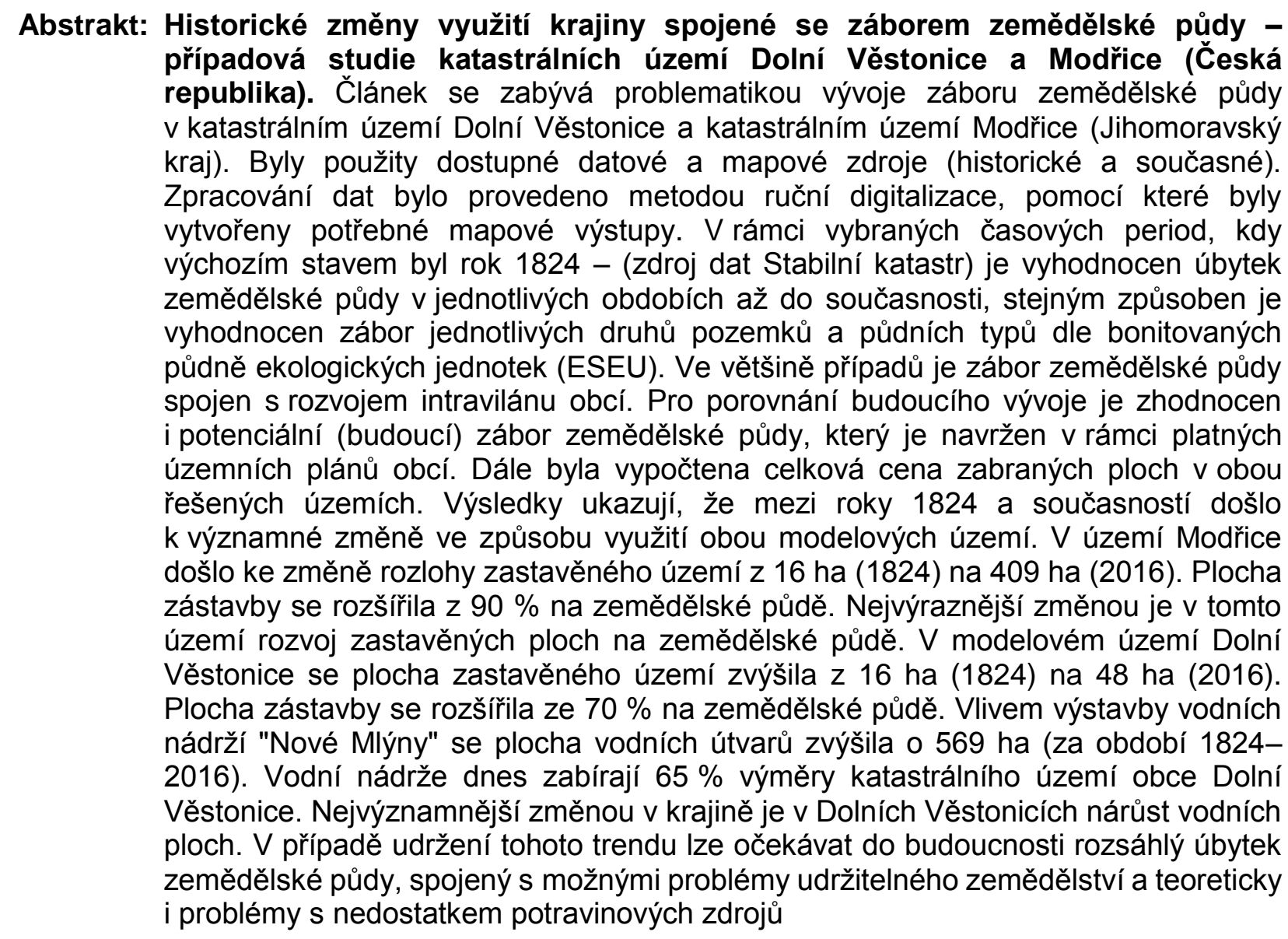


Klíčová slova: Zábor půdy, využití území, degradace, BPEJ, cena půdy, rozrůstání měst

\section{Introduction}

The landscape is an open system created by the mutual influence of natural processes and human undertakings (Antrop, 1998) that change over time and space. Since the beginning of human society's development, man has influenced the appearance of the landscape and the intensity and course of natural processes. The landscape changes continuously with the varying intensity and scope of changes. The intensity depends primarily on the location, the attractiveness of the land and the degree of maturity or development of society. Alternations in land use that reflect changes in approach to natural and socio-economic sphere in a specific area (Jeleček et al., 1999) are among the most visible manifestations. Landscape and its disposition are characterised in their uniqueness based on a remarkable variety of natural and cultural conditions (Kupka, 2010). Lokoč and Lokočová (2010) quoted that landscape can be visualised as a jointly-created and controllable organism. Lipský (2000) stated anthropogenic processes act very quickly and over a short space of time. These processes alter the appearance, structure and function of the landscape directly (surface mines, ploughing, planting, etc.) or indirectly (erosion, ecological succession, etc.) The most extensive and deepest changes to the landscape were offset by the industrial revolution in the mid- $18^{\text {th }}$ century and intensified in the second half of $20^{\text {th }}$ century. Creating large soil expanses of arable land and the destruction of landscape elements with an environmental function during agricultural collectivisation had a drastic impact on the face of our countryside.

Soil and landscape are degraded in their quality (soil erosion, nutrients washing out, soil compacting, landscape homogenisation, falls in biodiversity and fragmentation of landscape structure), as well as lost completely in terms of their quantity. However, at present, soil sealing for other, non-agricultural purposes can be considered as one of the gravest degradation factors.

Urban development, by far the most rapidly expanding land use type in Europe, puts peri-urban areas under particular pressure: the growth of built development in peri-urban areas is likely to be up to four times as fast as in urban areas. The risk is urban sprawl and soil sealing (Piorr, Ravetz, Tosics, 2011). Urban sprawl is associated with a number of ecological, economic and social effects. However, urban sprawl has detrimental and long-lasting effects. For example, urban sprawl contributes significantly to the loss of fertile farmland, to soil sealing and to the loss of ecological soil functions. The increase in built-up areas reduces the size of wildlife habitats and increases landscape fragmentation and the spread of invasive species. Urban sprawl leads to higher greenhouse gas emissions, higher infrastructure costs for transport, water and electrical power, the loss of open landscapes, and the degradation of various ecosystem services (European Environmental Agency, 2016).

The development of human settlements and society changes landscape structure and the functional use of the land. Due to the expansion of towns and villages including ensuing infrastructure, agricultural land including the best crop-yielding areas has declined dramatically (Van der Heijde, 2012). In their work, Hersperger and Buergi, (2008) quantified the engines of landscape changes and discovered that urbanisation was the most important force of landscape and societal change in the three periods under scrutiny (the beginning, middle and the end of the $20^{\text {th }}$ century). Economic and political reasons only followed. Urban sprawl presents a major challenge with regard to sustainable land use, as the International Year of Soils 2015 highlighted. Sprawl is a result not only of population growth but also of lifestyles that take up more space (European Environmental Agency, 2016). Growing urban sprawl (dispersed urban development) is a serious concern worldwide for a number of environmental and socio-economic reasons. Since 2008, half of the planet's population has been living in cities and agglomerations, and this proportion is increasing at a rapid pace (UN, 2006; UNFPA, 2007). The global human population is likely to continue to increase rapidly, which will lead to a continued population shift from rural to urban areas and to significant additional land uptake for urban expansion (Montgomery, 2008; Gerland et al., 2014; UN, 2014). Nearly $73 \%$ of the European population live in cities, and this proportion is projected to reach $82 \%$ by 2050 (UN, 2012). 
The issue of agricultural soil sealing is both world-wide (Africa, China: sealing for quarrying, infrastructure) as well as specifically European (Netherlands, Italy, Germany: sealing for infrastructure and industry). At present, we are probably experiencing what is historically the most extensive obliteration of agricultural land.

The Food and Agriculture Organization of the United Nations (FAO) expects an increase of $43 \%$ in global food demand by 2030 (FAO, 2011). While there is competition for fertile land, it is most pronounced in continents with the largest population increases, namely Africa and Asia (Chen, 2007; UN, 2014; Lambin et al., 2001).

A European Union report (EU) asserted that between 1990 and 2000, at least 275 ha of soil were lost in the EU every day. Almost half of these areas is permanently covered with an impenetrable layer of buildings, streets or parking lots. This unfavourable movement threatens a lack of arable land and sources of underground water availability for future generations (Agrarheute, 2011). In the EU, the Member States with high sealing rates (exceeding $5 \%$ of the national territory) are Malta, the Netherlands, Belgium, Germany, and Luxembourg. Furthermore, high sealing rates exist across the EU and include all major urban agglomerations, and most of the Mediterranean coast. The latter experienced a $10 \%$ increase in soil sealing only during the 1990 s (Jankü, et al., 2016). Between 1990 and 2000 alone, more than 800,000 hectares were built on in Europe. This phenomenon is due to changing lifestyles more than increased population. The amount of space consumed per person has more than doubled over the past 50 years (European Environmental Agency, 2006). From 2000 to 2006, Europe lost $1120 \mathrm{~km}^{2}$ per year of natural and semi-natural areas (of which, on average, almost $50 \%$ was arable or cultivated land) to urban or other artificial land development (European Environmental Agency, 2016). There is a high probability that large areas (totalling approximately $77500 \mathrm{~km}^{2}$ ) of the European continent will be or have been converted to urban areas between 2000 and 2030 (Seto et al., 2012).

Accordingly, urban sprawl has increased even in regions with a declining human population. Many more urban development and transport infrastructure projects are planned for the future, in particular in the European Union (EU) Member States which joined after 2004. Consequently, further increases in urban sprawl in the future will be significant (European Environmental Agency, 2016).

The loss of agricultural land is not only a development of cities and infrastructure in all cases. Agricultural land is also degraded and occupied due to the construction of water reservoirs (dams) and extensive afforestation (Science for Environment Policy, 2012).

In the Czech Republic, the conversion of farmland to urban uses (soil sealing) represents a very serious problem. On arable land in particular, there is a trend of soil loss (approximately $9100 \mathrm{ha} /$ year), which means approximately $25 \mathrm{ha} /$ day, or an area equal to 40 football pitches per day (Janků et al. 2016). Since 1927, the Czech Republic has lost over 851 thousand hectares, i.e. $22.3 \%$ of agricultural soil (Charvát, 2010). Historically the worst period came between the years 1976 and 1981 when 37.9 ha of soil vanished every day. This trend is perceived as extremely unfavourable and represented one of the worst developments in Europe. The intensity of soil sealing in the Czech Republic has been oscillating around 25 ha of soil per day lately (Spilková, Šefrna. 2010).

Despite the existence of the agriculture land protection law (Law No. 334/1992 Coll.), land protection in the Czech Republic seems to be ineffective. Rectification of damages caused is a long-term process that is often, in the case of soil loss, irrecoverable (Podhrázská, Karásek, 2014).

The aim of the article is to evaluate the changes in landscape of two model areas in the Czech Republic and to highlight the significant decline of agricultural land in the last two centuries.

\section{Methodology and Data}

Statistical, spatial grid data and vector data were used as a basis for research utilising maps (historical maps and current orthophoto maps) provided by the State Administration of Land Surveying and Cadastre and also the Military Geography and Hydrometeorological Office in 
Dobruška (historical aerial snaps), together with the currently applicable landscape plan pertaining to this particular area. All data was compared in Microsoft Excel, SQL. All spatial data was processed by ArcGIS software. ArcGIS features, including Spatial Analyst, have been used to process the input maps. Data overlays were used to compare data. All map outputs are processed in ArcGIS software. The representative cadastral areas of Dolní Věstonice and Modrice were selected for the purposes of this article (South Moravia, Czech Republic). This countryside has undergone major changes in land use. The intention of the analysis was to present the local impacts of the expansive land appropriation, made for the facilities with the supra-regional importance. In the first case it was construction of the flood protection and water retention basin connected with consequential development of recreation zones, in the second case, it was building-up the commercial and industrial estate, connected with the development of the traffic infrastructure.

\section{Evaluation of changes in Land Use}

The source for primary analysis of changes in the countryside and assessing the sealing of agricultural soil to the benefit of the progressing residential area were primarily digitalised maps of land use dated 1824 (stable cadastre - only residential area - built-up areas - covered; scale of maps 1:2880), 1836-1852 ( $2^{\text {nd }}$ military mapping; scale of maps 1:28800), 1876-1878 ( $3^{\text {rd }}$ military mapping, scale of map 1:25000), 1950 (aerial snaps), 1990 (orthophoto), 2006 (orthophoto) and 2016 (orthophoto). The selection of time horizons for analysing countryside structure was set with the intention of covering the most crucial alterations in landscape structure from the mid- $18^{\text {th }}$ century up to the present. A stable cadastre was set as the starting point. The current situation at the opposite end of the time scale is depicted by a colour orthophoto dated 2016. Another part of the analysis used the available Dolní Věstonice and Modrice landscape plans that stipulate the manner of using village land in future. As in the case of the stable cadastre, only the residential area was covered in the case of the landscape plan.

Maps showing landscape cover were generalised by manually digitalising the source materials to the range of the area in question. The digitalisation outputs are Land Use SC (stable cadastre), 2MM, 3MM (military mapping), 1950, 1990, 2006 and 2016, LS plan (Landscape plan). Land Use layers contain land categories: arable land, permanent grassland, forest, vineyard, orchard, water, other areas and built-up areas.

For the purposes of ascertaining the theoretical future development of built-up areas, the coverage of built-up areas in 2100 was calculated using a method for stipulating the annual intensity of residential area expansion from the stable cadastre until 2016 (X ha/year) and applying this figure up until the year 2100 .

The built-up area category was selected from analysed land use. The development of residential area expansion was analysed for the period under scrutiny.

\section{Evaluation of changes in land characteristics}

To evaluate agricultural land and its productive capacity expressed in prices, in the 1970s, the Czech Republic introduced the "Land Evaluation Information System". This system contains basic data on the land defined using a 5-digit code, forming together an Evaluated Soil-Ecological Unit (ESEU). Each of the digits (or pair of digits) expresses a particular land characteristic. The system of evaluated soil-ecological units reflects all characteristics and differences in a particular agronomical area (soil, climatic and morphological conditions). Regionalization of individual ESEU and their corresponding codes is done based on a digital collection of ESEU maps, using the borderlines surrounding individual ESEU surfaces with their numerical designation (Mašát et al. 2002).

The structure of the ESEU code is defined in the following way:

\section{A.BB.C.D.}

A - climatic region code (0-9)

BB - code of the main soil unit (0-78) 
C - combined code of slope and exposure (0-9)

$\mathrm{D}$ - combined code of skeletality and soil depth (0-9)

Changes to these soil characteristics were used to assess the qualitative degradation of agricultural soil due to expansion of built-up areas. This assessment was divided into three time periods (second military mapping (1836-1852) - 2016; 1950 - 2016; 2016 - Landscape plan of the village).

Based on the Decree No. 441/2013 Sb., the official price is fixed for every ESEU $\left(€ / \mathrm{m}^{2}\right)$. By comparing lost land due to the build-up and the price of land (Decree No. 441/2013), we can determine the total price of degraded land (Podhrázská et al., 2015).

This approach was applied to the assessment of economic impacts of soil sealing in the model localities Dolní Věstonice and Modřice.

\section{Characteristics of the area}

Modrice is a town in the Brno-venkov district in the South Moravian region immediately neighbouring the city of Brno. It is located on the edge of Dyje-Svratka valley and its cadastral area covers 1005.04 ha.

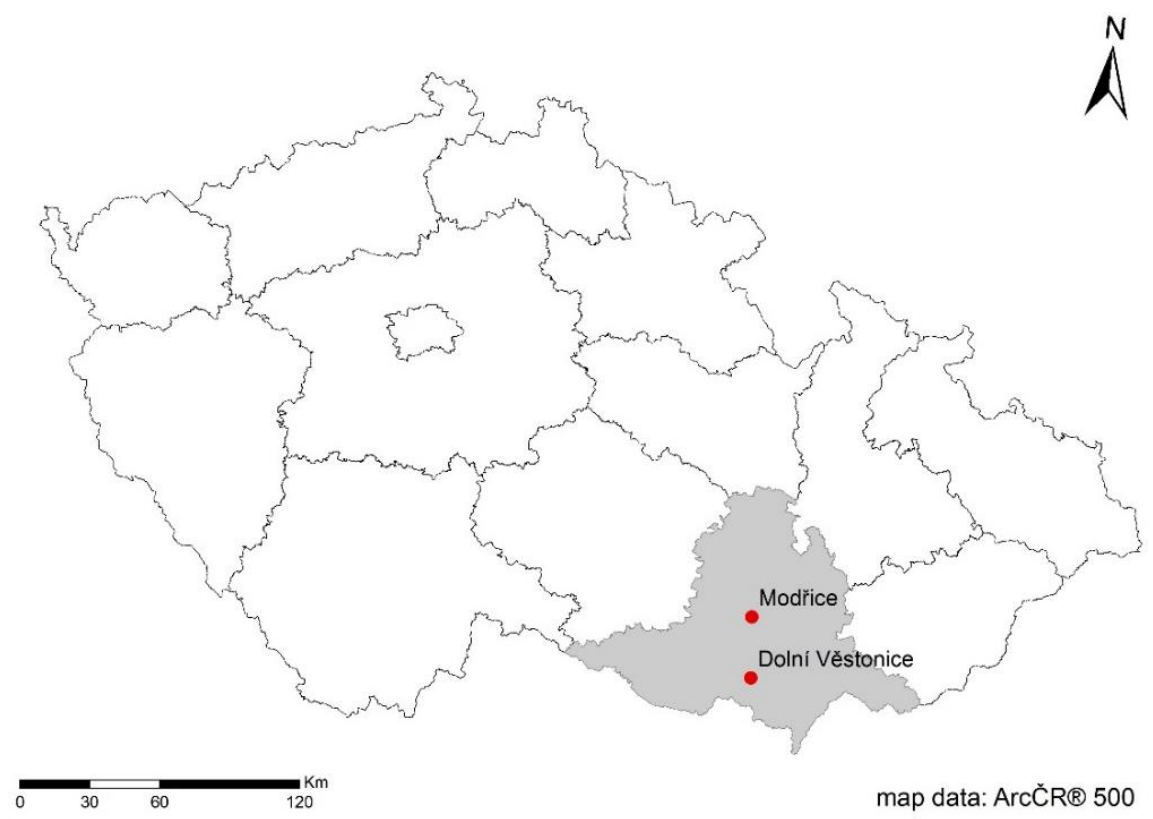

Fig 1. Location of model cadastral areas Modrice and Dolní Věstonice in the Czech Republic.

Dolní Věstonice is located at the foot of the northern slopes of Pavlovské vrchy on the Dyje's right bank. Once the Nové Mlýny reservoirs were filled, the village found itself on their shores behind a preserved section of the original river bed. The settlement is positioned on the old trading route between Austria and Moravia that even today links Mikulov and Hustopeče and follows the bank between the central and lower Nové Mlýny reservoirs leading to Strachotín. The cadastral acreage of the village is 880.04 ha. Fig. 1 presents surveillance map of both areas under scrutiny.

\section{Results and Discussion}

Generated land use maps mediate information on land use from a historical point until the present, including the state proposed in the municipal landscape plan.

\section{Land Use $-2^{\text {nd }}$ military mapping (1836-1852)}

Land use analyses were first carried out in the period of the second military mapping (2MM) between 1836 and 1852. The analyses carried out in the Modrice cadastre suggest that arable 
land, i.e. $69.18 \%$ (Table 1) was the most frequently represented at that time. Permanent grassland came second, taking up $17-83 \%$. Forests with $8.31 \%$, vineyards with $2.13 \%$ and orchards with $0.21 \%$ followed. Built-up areas covered $2.34 \%$ of the cadastral area.

In the case of Dolní Věstonice, it is mostly forests with $35.22 \%$ of the cadastre area (Table 1), followed closely by permanent grassland (31.1\%). Arable land is the third most wide-spread land use category with $21.82 \%$. Less area is covered by vineyards $(8.58 \%)$ and orchards $(0.54 \%)$. Built-up area coverage attains 24.13 ha $(2.74 \%)$.

Tab 1. The schedule of the land use categories and their area in II military mapping (1832-1852).

\begin{tabular}{|l|r|r|l|l|r|r|}
\hline Modřice & \multicolumn{1}{|c|}{ ha } & \multicolumn{1}{c|}{$\%$} & & Dolní Věstonice & \multicolumn{1}{c|}{ ha } & \multicolumn{1}{c|}{$\%$} \\
\hline Forest & 83.53 & 8.31 & & Forest & 309.92 & 35.22 \\
\hline Arable land & 695.33 & 69.18 & & Arable land & 192.01 & 21.82 \\
\hline Orchard & 2.13 & 0.21 & & Orchard & 4.77 & 0.54 \\
\hline $\begin{array}{l}\text { Permanent } \\
\text { grassland }\end{array}$ & 179.24 & 17.83 & & $\begin{array}{l}\text { Permanent } \\
\text { grassland }\end{array}$ & 273.67 & 31.1 \\
\hline Vineyard & 21.28 & 2.13 & & Vineyard & 75.54 & 8.58 \\
\hline Water area & 0 & 0 & & Water area & 0 & 0 \\
\hline Built-up area & 23.53 & 2.34 & & Built-up area & 24.13 & 2.74 \\
\hline Total & 1005.04 & 100 & & Total & 880.04 & 100 \\
\hline
\end{tabular}

\section{Land Use - $3^{\text {rd }}$ military mapping (1876-1878)}

The second time period selected was the term of the third military mapping (3MM) that gives a similar view of the usage of land in both compared locations. Having carried out Modrice cadastre mapping, it transpired that the arable land category dominated taking up $87.47 \%$ of the whole area as against the previous mapping period. The result pointed to dramatic decrease in forest culture $(0.46 \%)$ and permanent grassland $(6.45 \%)$. To a lesser degree, orchards $(0.22 \%)$, vineyards (1.5\%) and other land that takes up $0.37 \%$ of the cadastre are represented. When assessing the scope of built-up area, a growth of about 11 ha became apparent which represents some $3.53 \%$ of the overall built-up area (Table 2).

Forests are the highest represented type of land cover in the Dolní Věstonice cadastre with $34.34 \%$, followed by permanent grassland, where the coverage increased by 6 ha $(31.79 \%)$, whilst the orchards dropped $(0.19 \%)$. A small reduction of arable land can be observed in this period (19.83\%) and an increase in vineyards (10.92\%). Built-up land took up 25.8 ha in this period, i.e. $2.93 \%$ of the cadastre.

Tab 2. The schedule of the land use categories and their area in III military mapping (1876-1878).

\begin{tabular}{|l|r|r|}
\hline Modřice & \multicolumn{1}{|c|}{ ha } & \multicolumn{1}{c|}{$\%$} \\
\hline Forest & 4.63 & 0.46 \\
\hline Arable land & 879.09 & 87.47 \\
\hline Orchard & 2.17 & 0.22 \\
\hline $\begin{array}{l}\text { Permanent } \\
\text { grassland }\end{array}$ & 64.84 & 6.45 \\
\hline Vineyard & 15.03 & 1.5 \\
\hline Water area & 0 & 0 \\
\hline Other area & 3.83 & 0.37 \\
\hline Built-up area & 35.45 & 3.53 \\
\hline Total & 1005.04 & 100 \\
\hline
\end{tabular}

\begin{tabular}{|l|r|r|}
\hline Dolní Věstonice & \multicolumn{1}{|c|}{ ha } & \multicolumn{1}{c|}{$\%$} \\
\hline Forest & 302.22 & 34.34 \\
\hline Arable land & 174.54 & 19.83 \\
\hline Orchard & 1.64 & 0.19 \\
\hline $\begin{array}{l}\text { Permanent } \\
\text { grassland }\end{array}$ & 279.73 & 31.79 \\
\hline Vineyard & 96.11 & 10.92 \\
\hline Water area & 0 & 0 \\
\hline Built-up area & 25.8 & 2.93 \\
\hline Total & 880.04 & 100 \\
\hline
\end{tabular}




\section{Land Use - 1950}

The period of the 1950s is characterised by the beginnings of agricultural collectivisation in what was then Czechoslovakia. Arable land got redistributed into excessive soil blocks while green belts vanished from the countryside. The manner of land use has altered dramatically. The analysis carried out from 1950s data demonstrates that arable land in both cadastres takes up relatively high percentage of the overall acreage (Modřice $-86.04 \%$ and Dolní Věstonice $27.44 \%)$. In the Modřice cadastre, other cultures occupy a very small percentage of acreage (Table 3). On the other hand, forests are highly represented in the Dolní Věstonice area (40\%). These are followed to a large degree by permanent grassland $(23.45 \%)$ and vineyards taking up $5.45 \%$. Built-up areas increased in both locations under scrutiny against the previous period (Table 3).

Tab 3. The schedule of the land use categories and their area in 1950.

\begin{tabular}{|l|r|r|}
\hline Modřice & \multicolumn{1}{|c|}{ ha } & \multicolumn{1}{|c|}{$\%$} \\
\hline Forest & 3.82 & 0.38 \\
\hline Arable land & 864.71 & 86.04 \\
\hline Orchard & 21.59 & 2.15 \\
\hline $\begin{array}{l}\text { Permanent } \\
\text { grassland }\end{array}$ & 0 & 0 \\
\hline Vineyard & 0 & 0 \\
\hline Water area & 0 & 0 \\
\hline Other area & 5.83 & 0.58 \\
\hline Built-up area & 109.09 & 10.85 \\
\hline Total & 1005.04 & 100 \\
\hline
\end{tabular}

\begin{tabular}{|l|r|r|}
\hline Dolní Věstonice & \multicolumn{1}{|c|}{ ha } & \multicolumn{1}{|c|}{ \% } \\
\hline Forest & 352.06 & 40 \\
\hline Arable land & 241.48 & 27.44 \\
\hline Orchard & 0 & 0 \\
\hline $\begin{array}{l}\text { Permanent } \\
\text { grassland }\end{array}$ & 206.37 & 23.45 \\
\hline Vineyard & 47.95 & 5.45 \\
\hline Water area & 0 & 0 \\
\hline Built-up area & 32.18 & 3.66 \\
\hline Total & 880.04 & 100 \\
\hline
\end{tabular}

\section{Land Use - 1990}

Analysis of 1990, land use data (Table 4) brings fundamental changes to the use of landscape as against the previously analysed periods in both cadastral locations.

In the Modrice cadastre, arable land still prevails even though it dropped compared to the previous period down to $60.44 \%$. Orchards went up significantly (11.58\%). Besides, there was permanent grassland $(0.17 \%)$, forest $(1.34 \%)$, vineyards $(1.68 \%)$ and other areas $(1.32 \%)$. The analysis carried out suggests the second most frequently represented category is built-up area that now covers $23.47 \%$ of the total acreage, i.e. 235.94 ha. Development of the residential area can be attributed to the proximity of the Moravian capital Brno, i.e., the proximity of a large city, the development of infrastructure, migration of inhabitants to towns and their outskirts.

The forests in Dolní Věstonice that had prevailed up to that point vanish completely to be replaced by water, due to the construction of the Nové Mlýny reservoirs. These now cover more than half of the landscape under scrutiny. Arable land is the second most represented category $(17.08 \%)$, followed by vineyards $(6.86 \%)$, permanent grassland $(3.6 \%)$, forest $(1.63 \%)$ and orchard $(0.38 \%)$. Built-up area represents 33.16 ha $(3.77 \%)$. 
Tab 4. The schedule of land use categories and their area in 1990.

\begin{tabular}{|l|r|r|}
\hline Modřice & \multicolumn{1}{|c|}{ ha } & \multicolumn{1}{c|}{$\%$} \\
\hline Forest & 13.47 & 1.34 \\
\hline Arable land & 607.43 & 60.44 \\
\hline Orchard & 116.4 & 11.58 \\
\hline $\begin{array}{l}\text { Permanent } \\
\text { grassland }\end{array}$ & 1.67 & 0.17 \\
\hline Vineyard & 16.86 & 1.68 \\
\hline Water area & 0 & 0 \\
\hline Other area & 13.27 & 1.32 \\
\hline Built-up area & 235.94 & 23.47 \\
\hline Total & 1005.04 & 100 \\
\hline
\end{tabular}

\begin{tabular}{|l|r|r|}
\hline Dolní Věstonice & \multicolumn{1}{c|}{ ha } & \multicolumn{1}{c|}{$\%$} \\
\hline Forest & 14.38 & 1.63 \\
\hline Arable land & 150.35 & 17.08 \\
\hline Orchard & 3.36 & 0.38 \\
\hline $\begin{array}{l}\text { Permanent } \\
\text { grassland }\end{array}$ & 31.64 & 3.6 \\
\hline Vineyard & 60.36 & 6.86 \\
\hline Water area & 586.79 & 66.68 \\
\hline Built-up area & 33.16 & 3.77 \\
\hline Total & 880.04 & 100 \\
\hline
\end{tabular}

\section{Land Use - 2006}

An analogous situation can be observed in both cadastral areas. Arable land in the Modrice has a decreasing affinity, yet still takes up over $50 \%$ of the land. Forests $(1.94 \%)$, orchards $(14.99 \%)$ and grassland $(0.26 \%)$ demonstrated an increase in Dolní Věstonice too (Table 5$)$. The analysis shows the built-up acreage keeps increasing and occupies a substantial segment of the cadastral land (28.42\%).

Water areas were the most represented category in Dolní Věstonice in 2006 attaining $64.62 \%$ of the cadastre. The analyses show that arable land drops further (10.46\%). In the case of forest, orchard and vineyards, it is in fact an increase in acreage. Forests are represented by $5.59 \%$, orchards $1.16 \%$ and vineyards $10.24 \%$. Built-up area covers $37.98 \mathrm{ha}(4.32 \%)$.

Tab 5. The schedule of land use categories and their area in 2006.

\begin{tabular}{|l|r|r|}
\hline Modřice & \multicolumn{1}{|c|}{ ha } & \multicolumn{1}{c|}{$\%$} \\
\hline Forest & 19.54 & 1.94 \\
\hline Arable land & 546.62 & 54.39 \\
\hline Orchard & 150.66 & 14.99 \\
\hline $\begin{array}{l}\text { Permanent } \\
\text { grassland }\end{array}$ & 2.61 & 0.26 \\
\hline Vineyard & 0 & 0 \\
\hline Water area & 0 & 0 \\
\hline Built-up area & 285.61 & 28.42 \\
\hline Total & 1005.04 & 100 \\
\hline
\end{tabular}

\begin{tabular}{|l|r|r|}
\hline Dolní Věstonice & \multicolumn{1}{c|}{ ha } & \multicolumn{1}{c|}{$\%$} \\
\hline Forest & 49.22 & 5.59 \\
\hline Arable land & 92.05 & 10.46 \\
\hline Orchard & 10.19 & 1.16 \\
\hline $\begin{array}{l}\text { Permanent } \\
\text { grassland }\end{array}$ & 31.83 & 3.62 \\
\hline Vineyard & 90.12 & 10.24 \\
\hline Water area & 568.65 & 64.62 \\
\hline Built-up area & 37.98 & 4.32 \\
\hline Total & 880.04 & 100 \\
\hline
\end{tabular}

\section{Land Use - 2016}

Analysis of the present state in Modřice cadastral area shows two prevailing categories in the way of using the countryside - arable land $(45.21 \%$ ) and built-up areas $(40.68 \%)$. In case of the arable land, the acreage drops continuously for the benefit of built-up areas. Against the previous term (2006), the acreage of built-up areas grew by almost 123.32 ha. The built-up areas currently take up about $41 \%$ of the total cadastral acreage (Table 6).

At present situation in 2016, water prevails in Dolní Věstonice (64.98\%), followed by vineyards $(8.83 \%)$, arable land (which is dropping continuously - 8.3\%) and forests that take up $7.76 \%$. Compared to the previous period, the built-up land went up by a further about 10 ha to the total of 47.82 ha. 
Tab 6. The schedule of land use categories and their area in 2016.

\begin{tabular}{l|r|r}
\hline Modřice & \multicolumn{1}{|c|}{ ha } & \multicolumn{1}{c}{ \% } \\
\hline Forest & 36.11 & 3.59 \\
Arable land & 454.34 & 45.21 \\
Orchard & 62.53 & 6.22 \\
Permanent & 31.21 & 3.11 \\
grassland & 3.68 & 0.37 \\
Vineyard & 8.24 & 0.82 \\
Water area & 408.93 & 40.68 \\
Built-up area & 1005.04 & 100 \\
Total &
\end{tabular}

\begin{tabular}{l|r|r}
\hline Dolní Věstonice & \multicolumn{1}{c|}{ ha } & \multicolumn{1}{c}{$\%$} \\
\hline Forest & 68.33 & 7.76 \\
Arable land & 73.08 & 8.31 \\
Orchard & 12.54 & 1.42 \\
Permanent & 28.69 & 3.26 \\
grassland & 77.74 & 8.83 \\
Vineyard & 571.84 & 64.98 \\
Water area & 47.82 & 5.43 \\
Built-up area & 880.04 & 100 \\
Total & \multicolumn{2}{|c}{} \\
\hline
\end{tabular}

Tab 7. Temporary development of the area (ha) of land use categories in any period.

\begin{tabular}{|c|c|c|c|c|c|c|}
\hline Modřice & $2 \mathrm{MM}$ & $3 \mathrm{MM}$ & 1950 & 1990 & 2006 & 2016 \\
\hline Forest & 83.53 & 4.63 & 3.82 & 13.47 & 19.54 & 36.11 \\
\hline Arable land & 695.33 & 879.09 & 864.71 & 607.43 & 546.62 & 454.34 \\
\hline Orchard & 2.13 & 2.17 & 21.59 & 116.4 & 150.66 & 62.53 \\
\hline $\begin{array}{l}\text { Permanent } \\
\text { grassland }\end{array}$ & 179.24 & 64.84 & 0 & 1.67 & 2.61 & 31.21 \\
\hline Vineyard & 21.28 & 15.03 & 0 & 16.86 & 0 & 3.68 \\
\hline Water area & 0 & 0 & 0 & 0 & 0 & 8.24 \\
\hline Other area & 0 & 3.83 & 5.83 & 13.27 & 0 & 0 \\
\hline Built-up area & 23.53 & 35.45 & 109.09 & 235.94 & 285.61 & 408.93 \\
\hline Total & 1005.04 & 1005.04 & 1005.04 & 1005.04 & 1005.04 & 1005.04 \\
\hline Dolní Věstonice & $2 \mathrm{MM}$ & $3 \mathrm{MM}$ & 1950 & 1990 & 2006 & 2016 \\
\hline Forest & 309.92 & 302.22 & 352.06 & 14.38 & 49.22 & 68.33 \\
\hline Arable land & 192.01 & 174.54 & 241.48 & 150.35 & 92.05 & 73.08 \\
\hline Orchard & 4.77 & 1.64 & 0 & 3.36 & 10.19 & 12.54 \\
\hline $\begin{array}{l}\text { Permanent } \\
\text { grassland }\end{array}$ & 273.67 & 279.73 & 206.37 & 31.64 & 31.83 & 28.69 \\
\hline Vineyard & 75.54 & 96.11 & 47.95 & 60.36 & 90.12 & 77.74 \\
\hline Water area & 0 & 0 & 0 & 586.79 & 568.65 & 571.84 \\
\hline Built-up area & 24.13 & 25.8 & 32.18 & 33.16 & 37.98 & 47.82 \\
\hline Total & 880.04 & 880.04 & 880.04 & 880.04 & 880.04 & 880.04 \\
\hline
\end{tabular}

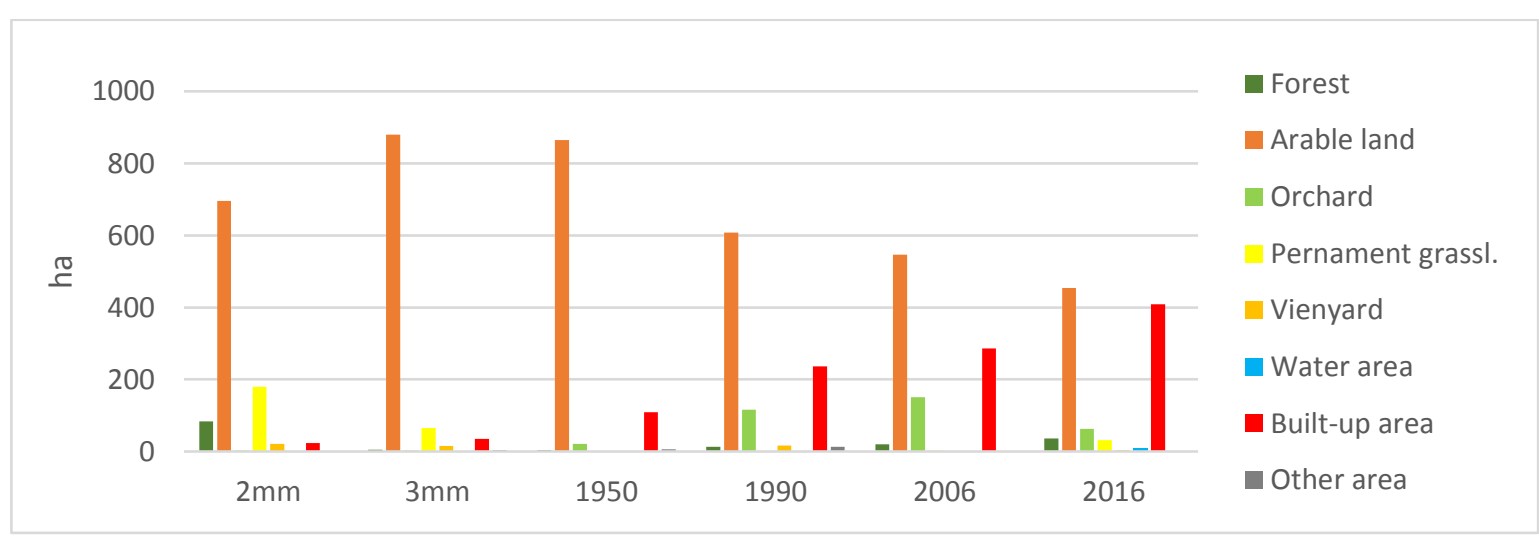




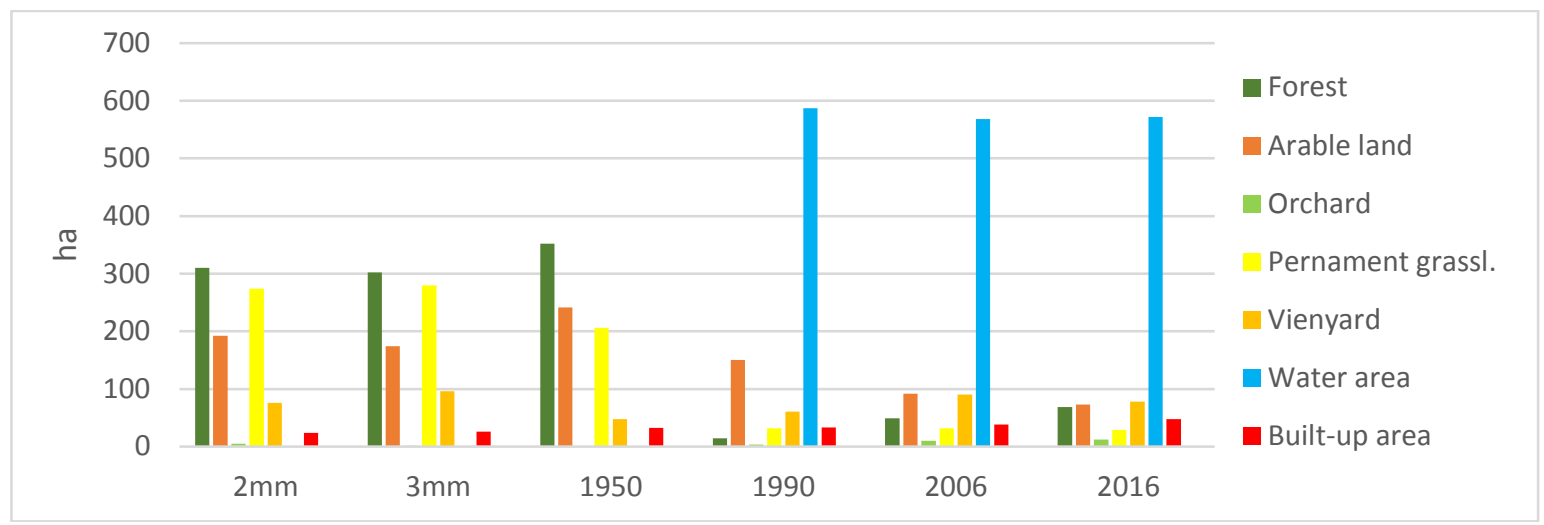

Fig 2. Graphical visualisation of land use in all time periods (Modřice - above, Dolní Věstonice - below).

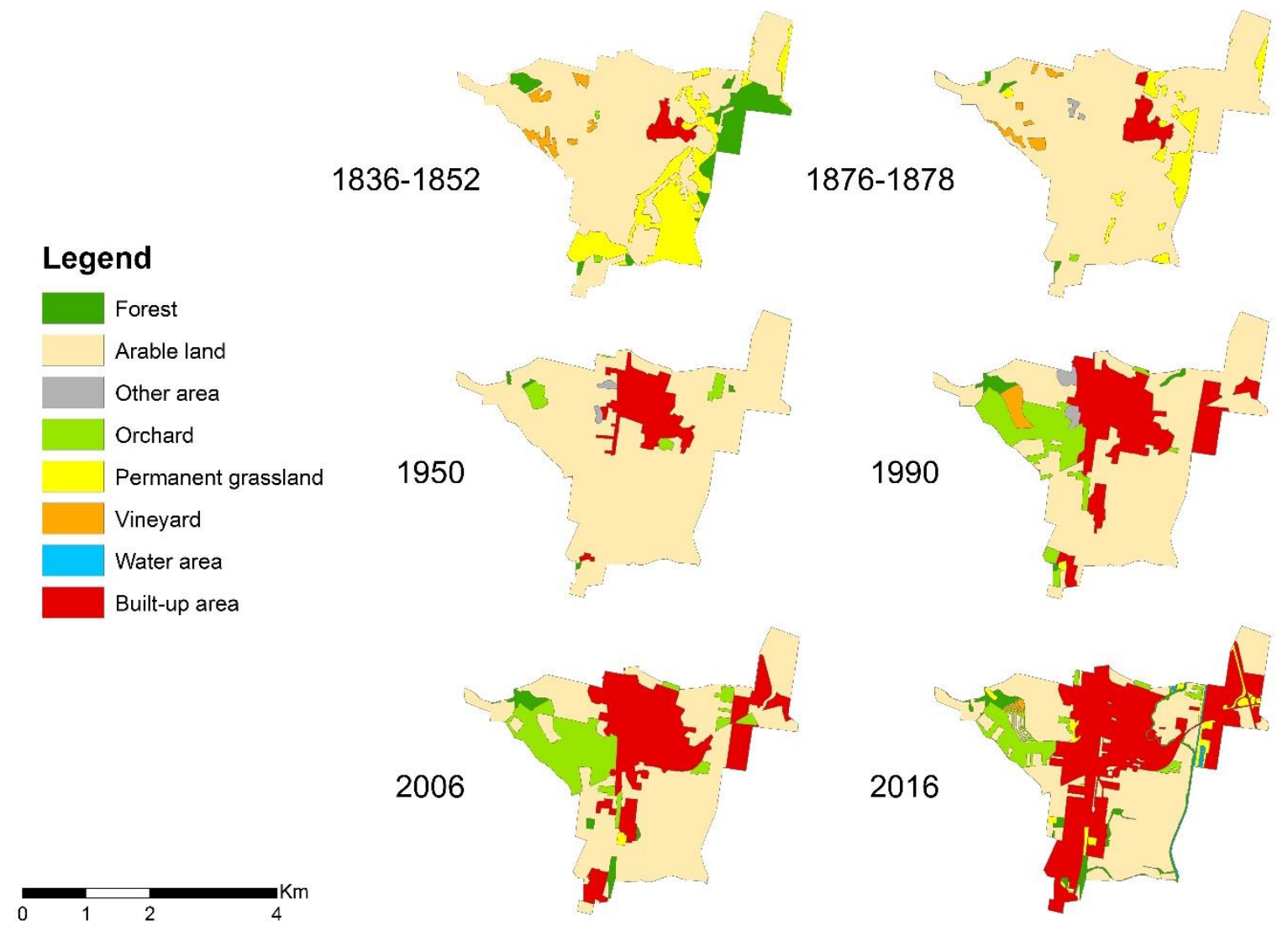

Fig 3. Land Use of Modrice cadastre in the analysed time period. 


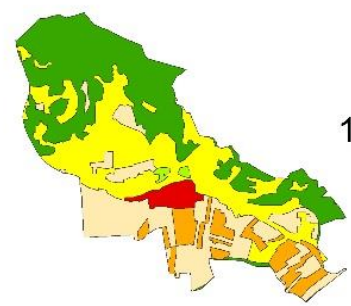

$1876-1878$

Legend
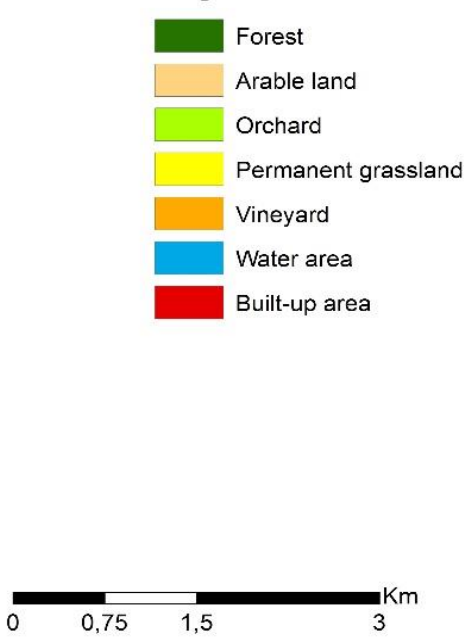

1950
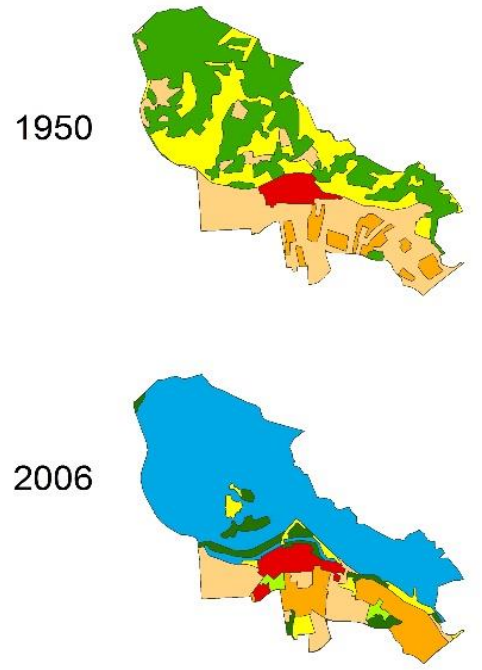

1990
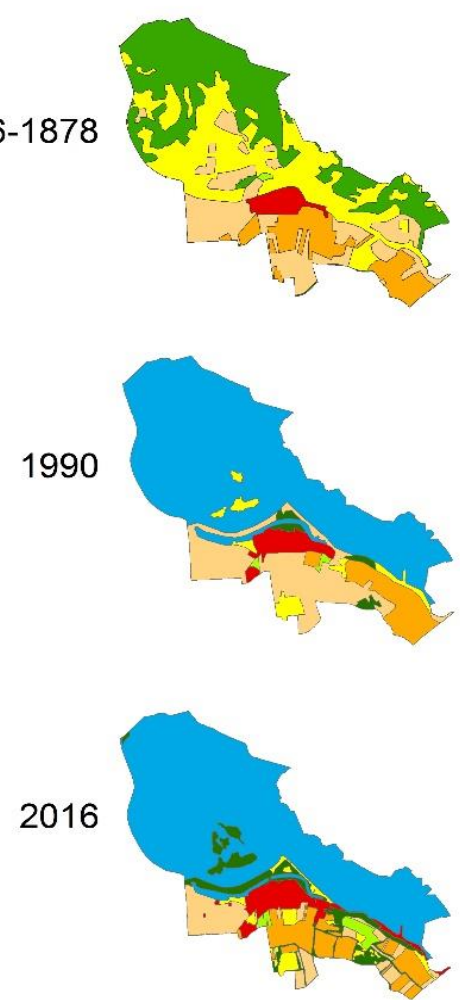

Fig 4. Land Use of Dolní Věstonice cadastre in the analysed time period.

\section{Assessment of agricultural land sealing}

Assessment of agricultural land sealing in favour of built-up areas was produced for 8 time series including the stable cadastre (SC) dated 1824, proposed state in the municipal landscape plans and theoretical situation in 2100 .

\section{Modřice Cadastral area}

Historical mapping images and pictures of the stable cadastre formed the source for assessing the total sealing of built-up areas (Fig. 6) that represents 13.11 ha. At the time of the second military mapping (1836-1852), the built-up areas expanded to 23.53 ha. At the time of third military mapping, there was a further increase in built-up areas by about 12 ha. From 1950 until the present, the overall acreage of residential areas grew to 408.93 ha corresponding to about $41 \%$ of the acreage. A total sealing of 123.29 ha has occurred in the last ten years (2006-2016). Yet the municipal landscape plan proposes sealing further ca 40 ha of soil. The potential scope of sealing to the benefit of built-up areas in 2100 was ascertained from the obtained results and it can take up as many as $59 \%$ of the location under scrutiny (Figure 5).

Tab 8. Development of built-up areas in Modrice cadastre.

\begin{tabular}{|l|r|r|}
\hline \multicolumn{1}{|c|}{ Period } & Built-up area (ha) & \% of cadastral area \\
\hline SC & 13.11 & 1.3 \\
\hline 2 MM & 23.53 & 2.34 \\
\hline 3 MM & 35.45 & 3.53 \\
\hline 1950 & 109.09 & 10.85 \\
\hline 1990 & 235.91 & 23.47 \\
\hline 2006 & 285.61 & 28.42 \\
\hline 2016 & 408.93 & 40.68 \\
\hline LS plan & 448.99 & 44.67 \\
\hline 2100 & 581.97 & 57.91 \\
\hline
\end{tabular}




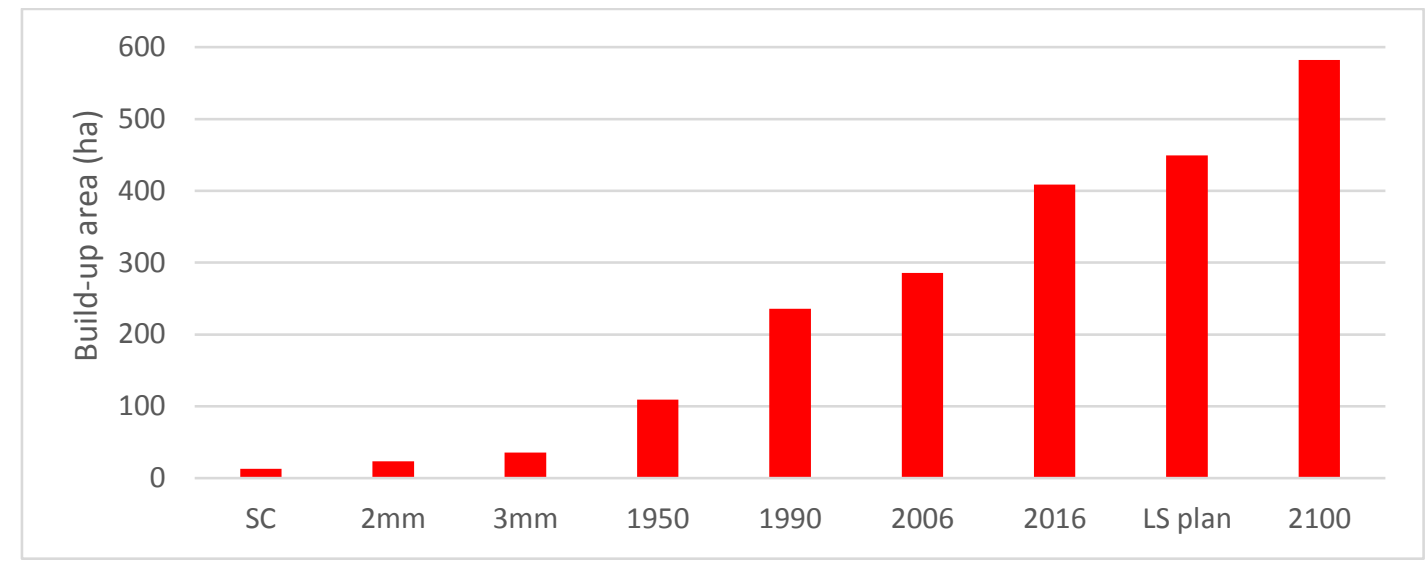

Fig 5. Graphical representation of the development of built-up areas - Modrice.

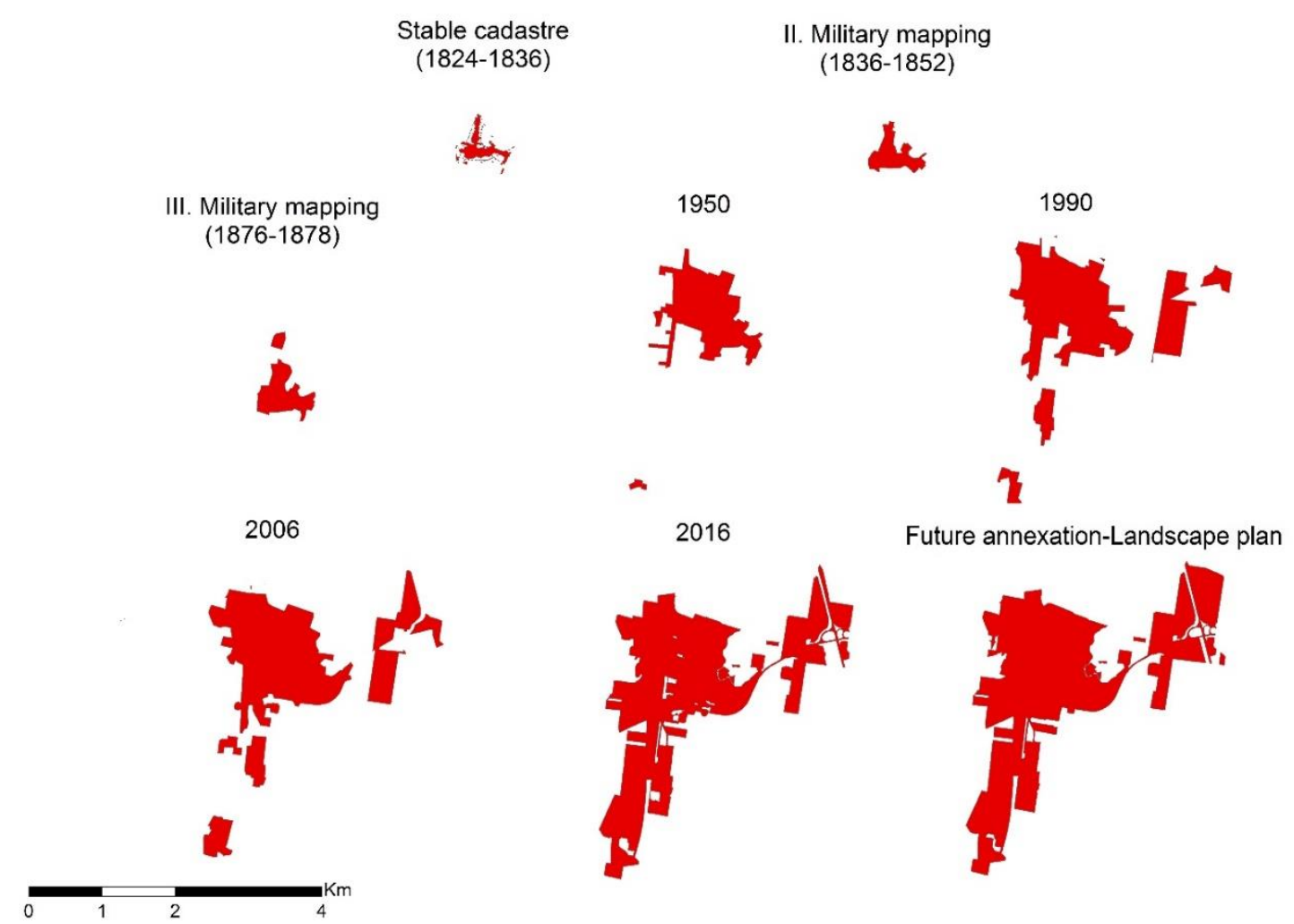

Fig 6. Maps of built-up areas in the analysed time period-Modrice cadastre.

Analysis of the decrease in land use categories showed that most sealed category in all the time periods under scrutiny was arable land (more than $80 \%$ of built-up area in all instances). The table 9 below shows the total scope of sealed cultures in individual time periods. 
Tab 9. Sealing of land use categories - Modrice.

\begin{tabular}{|l|r|r|r|r|r|r|}
\hline \multirow{2}{*}{ LU category } & \multicolumn{2}{|c|}{$2 \mathrm{MM}-1950$} & \multicolumn{2}{c|}{$1950-2016$} & \multicolumn{2}{c|}{ 2016-LS plan } \\
\cline { 2 - 7 } & \multicolumn{1}{|c|}{ ha } & \multicolumn{1}{c|}{$\%$} & \multicolumn{1}{c|}{ ha } & \multicolumn{1}{c|}{ \% } & \multicolumn{1}{c|}{ ha } & \multicolumn{1}{c|}{$\%$} \\
\hline Arable land & 83.68 & 97.37 & 291.52 & 96.41 & 34.07 & 85.05 \\
\hline Permanent grassland & 1.97 & 2.29 & 0 & 0 & 2.74 & 6.82 \\
\hline Vineyard & 0 & 0 & 0 & 0 & 0 & 0 \\
\hline Orchard & 0.22 & 0.26 & 4.45 & 1.47 & 2.73 & 6.82 \\
\hline Forest & 0.07 & 0.08 & 1.61 & 0.54 & 0.51 & 1.27 \\
\hline Other area & 0 & 0 & 4.78 & 1.58 & 0 & 0 \\
\hline Total & $\mathbf{8 5 . 9 4}$ & $\mathbf{1 0 0}$ & $\mathbf{3 0 2 . 3 6}$ & $\mathbf{1 0 0}$ & $\mathbf{4 0 . 0 6}$ & $\mathbf{1 0 0}$ \\
\hline
\end{tabular}

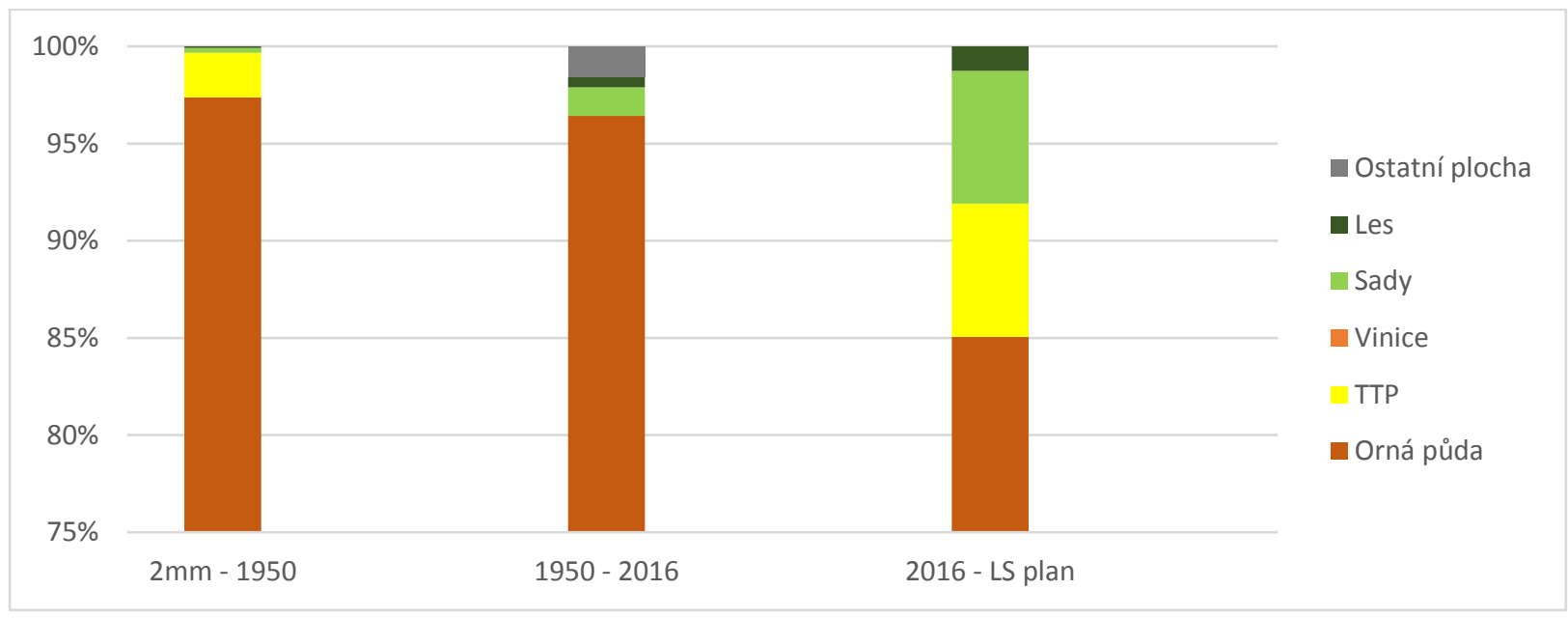

Fig 7. Graphical representation of the percentage of sealed cultures.

Qualitative analysis of agricultural land carried out, expressed by the decrease of Evaluated SoilEcological Units demonstrates the built-up ESEU in individual monitored periods.

Description of ESEU in Modřice cadastre

0.01.00, 2.01.00, 2.01.10 - Flat and moderately sloped Haplic Chernozems, soils with thick humus horizon, with crumb to granular structure, developed from loose carbonate substrates, deep soil

0.08.00 - Washed-off (eroded) Haplic Chernozems with cultivated substrate covering more than $50 \%$ of moderately sloped area

2.02.00, 2.02.10 - Flat and moderately sloped Luvic Cheznozems, without skeleton, predominantly with favourable water regime

2.08.10, 2.08.50 - Washed-off (eroded) Haplic Chernozems with cultivated substrate, in moderately sloped and sloped terrain

2.10.00 - Flat and moderately sloped Haplic Luvisoils, with heavier bottom, skeleton-less, deep, moderately sloped

2.56.00, 2.57.00 - Flat and moderately sloped Fluvisoils, deep soil profile, slightly dry climatic region

2.61.00 - Flat and moderately sloped Phaeozems, deep soil profile, slightly dry climatic region 99 - no agricultural land 
Tab 10. Sealing of individual ESEU and total price of degraded soil by the decree no 441/2013-Modrice.

\begin{tabular}{|c|c|c|c|c|c|c|c|c|c|c|}
\hline \multirow[b]{2}{*}{ ESEU } & \multirow[b]{2}{*}{$\begin{array}{l}\text { Price of } \\
\text { ESEU } \\
\left(€ / \mathrm{m}^{2}\right)\end{array}$} & \multicolumn{3}{|c|}{$2 \mathrm{MM}-1950$} & \multicolumn{3}{|c|}{ 1950-2016 } & \multicolumn{3}{|c|}{ 2016-LS plan } \\
\hline & & ha & $\%$ & $\begin{array}{c}\text { Total } \\
\text { price }(€)\end{array}$ & ha & $\%$ & $\begin{array}{c}\text { Total } \\
\text { price }(€)\end{array}$ & ha & $\%$ & $\begin{array}{c}\text { Total } \\
\text { price }(€)\end{array}$ \\
\hline 0.01 .00 & 0.62 & 0 & 0 & 0 & 0.11 & 0.04 & 682 & 0 & 0 & 0 \\
\hline 0.08 .10 & 0.44 & 0 & 0 & 0 & 3.89 & 1.29 & 17,116 & 0 & 0 & 0 \\
\hline 2.01 .00 & 0.64 & 66.64 & 77.54 & 426,496 & 67.73 & 22.4 & 433,472 & 7.03 & 17.55 & 44,992 \\
\hline 2.01 .10 & 0.57 & 0.93 & 1.08 & & 15.89 & 5.26 & & 2.9 & 7.24 & 530 \\
\hline 2.02 .00 & 0.64 & 4.84 & 5.63 & 30,976 & 46.97 & 15.53 & 300 & 1.31 & 3.27 & 8,384 \\
\hline 2.02 .10 & 0.57 & 0.35 & 0.41 & 1,995 & 12.63 & 4.18 & & 4.83 & 12.06 & 27,531 \\
\hline 2.08 .10 & 0.44 & 0 & 0 & 0 & 9.05 & 2.99 & 39,820 & 1.08 & 2.7 & 4,752 \\
\hline 2.08 .50 & 0.37 & 0 & 0 & 0 & 9.24 & 3.05 & & 0.27 & 0.67 & 999 \\
\hline 2.10 .00 & 0.59 & 0 & 0 & 0 & 0.36 & 0.12 & 2,124 & 0 & 0 & 0 \\
\hline 2.56 .00 & 0.52 & 11.27 & 13.11 & 58,604 & 101.84 & 33.68 & 529,568 & 19.19 & 47.9 & 99,788 \\
\hline 2.57 .00 & 0.43 & 0 & 0 & 0 & 1.65 & 0.55 & 7,095 & 3.13 & 7.81 & 13,459 \\
\hline 2.61 .00 & 0.54 & 0 & 0 & 0 & 3.85 & 1.27 & 20,790 & 0 & 0 & 0 \\
\hline 99 & 0 & 1.91 & 2.23 & 0 & 29.15 & 9.64 & 0 & 0.32 & 0.8 & 0 \\
\hline Total & & 85.94 & 100 & 523,372 & 302.36 & 100 & $1,548,027$ & 40.06 & 100 & 216,435 \\
\hline
\end{tabular}

The total surface of the sealed soil between $2^{\text {nd }}$ military mapping and present $(2016)$ is $388.3 \mathrm{ha}$. The total soil price of this area is 2,071,399 EUR.

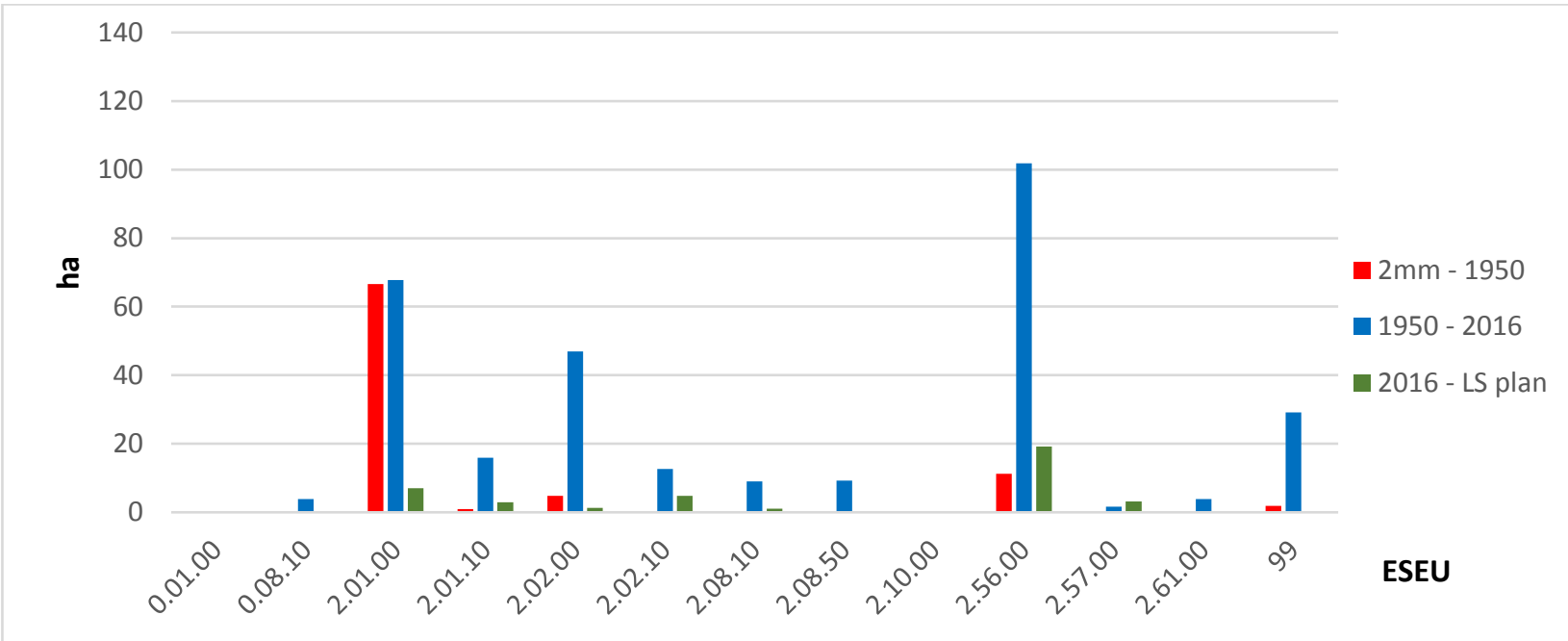

Fig 8. Graphical representation of sealed Evaluated Soil-Ecological Units.

\section{Dolní Věstonice cadastral area}

The scope of built-up areas in the onset period (year 1824 - stable cadastre) was 16.49 ha. The built-up area increased by 7.64 ha by the time of the second military mapping. There is no notable change at the time of the third military mapping. Land use analysis in 1950 demonstrates an increase of built-up areas by 32.18 ha against the starting point (growth by 6.38 ha compared to the previous period). Between 1950 and 2006, a 5.8 ha area was sealed (Table 11). In the most recent ten years (2006-2016), the extent of built-up area grew by a further 9.83 ha. According to the municipal landscape plan (LS plan), approximately 10 ha more soil should be sealed (Fig. 9, Fig. 10). Based on the results thus obtained, it is possible to anticipate a further increase in builtup areas by 2100 . 
Tab 11. Expansion of built-up areas in the Dolní Věstonice cadastre.

\begin{tabular}{|l|r|r|}
\hline \multicolumn{1}{|c|}{ Period } & Build-up area (ha) & \% of cadastral area \\
\hline SC & 16.49 & 1.87 \\
\hline 2 MM & 24.13 & 2.74 \\
\hline 3 MM & 25.8 & 2.93 \\
\hline 1950 & 32.18 & 3.66 \\
\hline 1990 & 33.16 & 3.77 \\
\hline 2006 & 37.98 & 4.32 \\
\hline 2016 & 47.81 & 5.43 \\
\hline LS plan & 57.76 & 6.56 \\
\hline 2100 & 61.5 & 6.99 \\
\hline
\end{tabular}

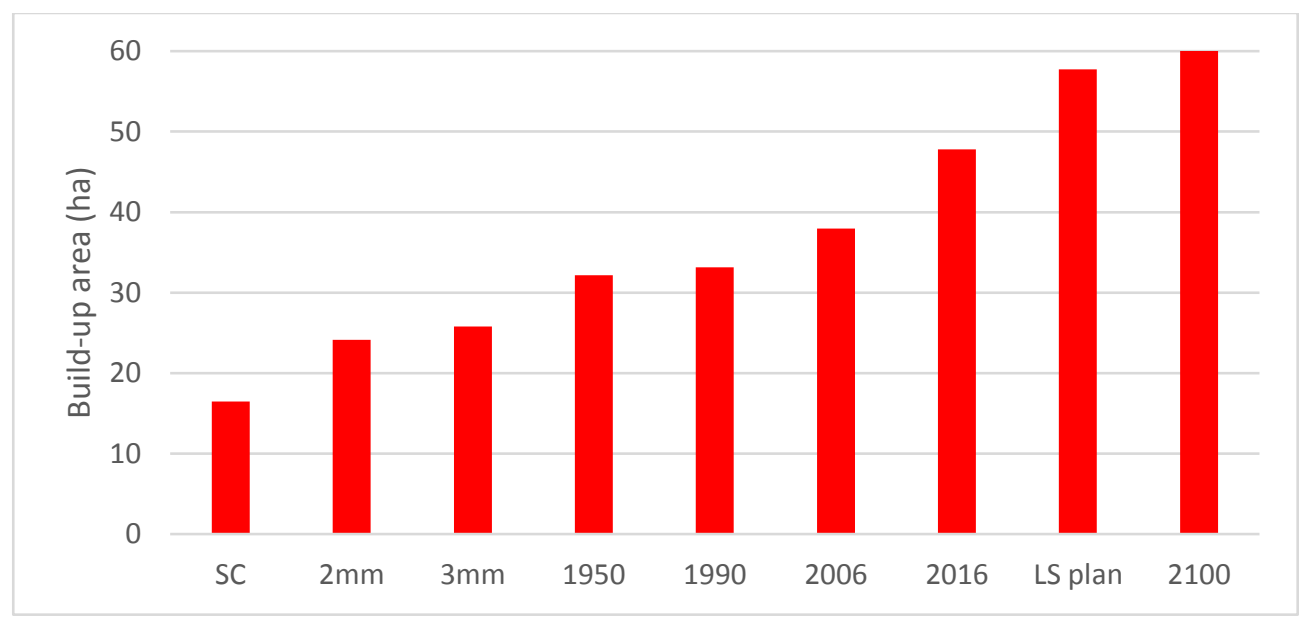

Fig 9. Graphical representation of the built-up areas development-Dolní Věstonice.

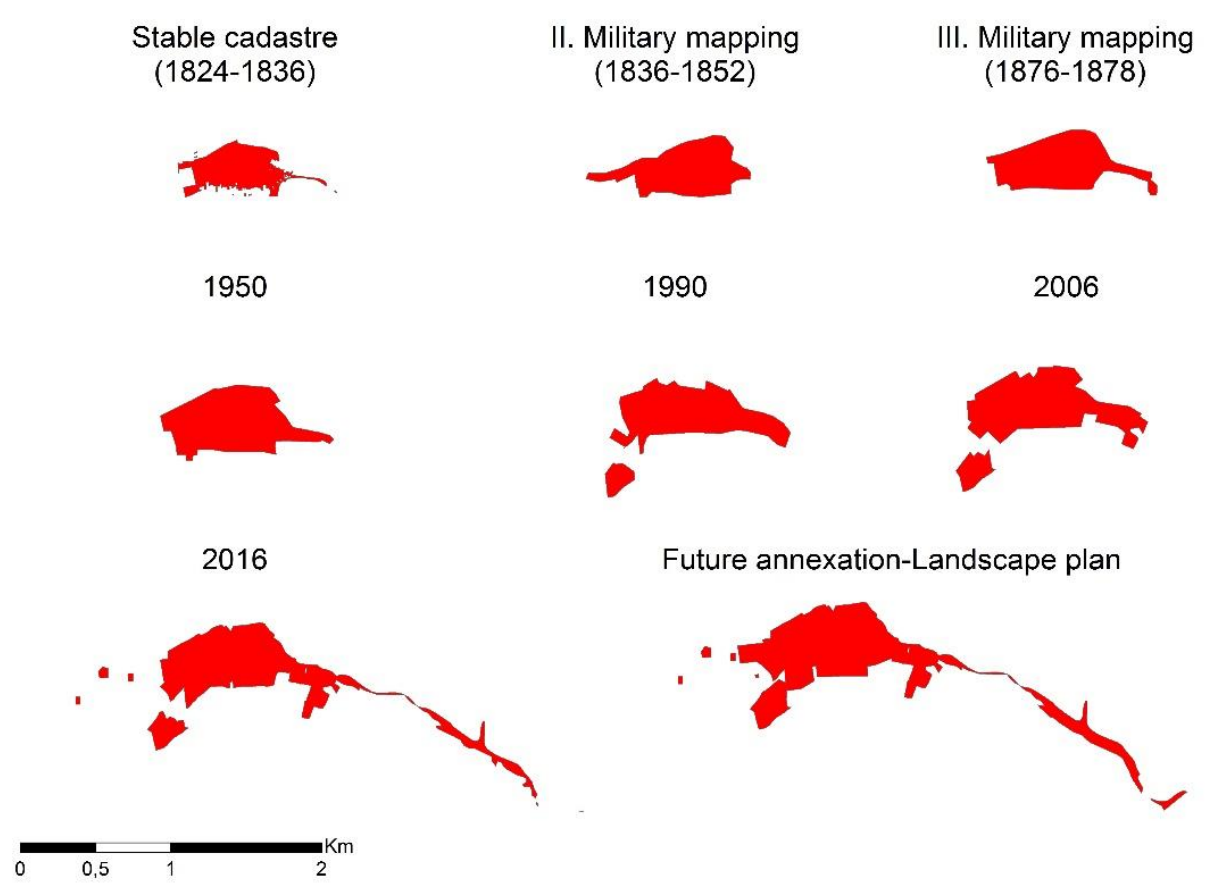

Fig 10. Maps of built-up areas in the analysed time period - Dolni Věstonice cadastre. 
Another part analyses the decrease in individual types of plot and soil (expressed by soil characteristics - Evaluated Soil-Ecological Units (ESEU)) due to the development of residential areas for the selected time period. The first to be assessed was the sealing of land between the second military mapping (1836-1852) up until the 1950. A total of 4.61 ha of arable land 1.33 ha vineyards and 3.59 ha permanent grassland were sealed for the purposes of built-up areas. The period 1950-2016 was assessed similarly as well as the sealing of different types of land as proposed by the landscape plan (2016-LS plan). The sealing results are demonstrated in Table 12 and Fig. 11.

Tab 12. Sealing of land use categories - Dolní Věstonice.

\begin{tabular}{|c|c|c|c|c|c|c|}
\hline \multirow{2}{*}{ LU category } & \multicolumn{2}{|c|}{$2 \mathrm{MM}-1950$} & \multicolumn{2}{|c|}{ 1950-2016 } & \multicolumn{2}{|c|}{ 2016-LS plan } \\
\hline & ha & $\%$ & ha & $\%$ & ha & $\%$ \\
\hline Arable land & 4.61 & 48.37 & 19.05 & 98.46 & 2.33 & 23.58 \\
\hline Permanent grasslands & 3.59 & 37.67 & 0.11 & 0.57 & 4.1 & 41.51 \\
\hline Vineyard & 1.33 & 13.96 & 0.007 & 0.04 & 0.84 & 8.47 \\
\hline Orchard & 0 & 0 & 0 & 0 & 1.07 & 10.8 \\
\hline Forest & 0 & 0 & 0.18 & 0.93 & 1.54 & 15.64 \\
\hline Total & 9.53 & 100 & 19.35 & 100 & 9.88 & 100 \\
\hline
\end{tabular}

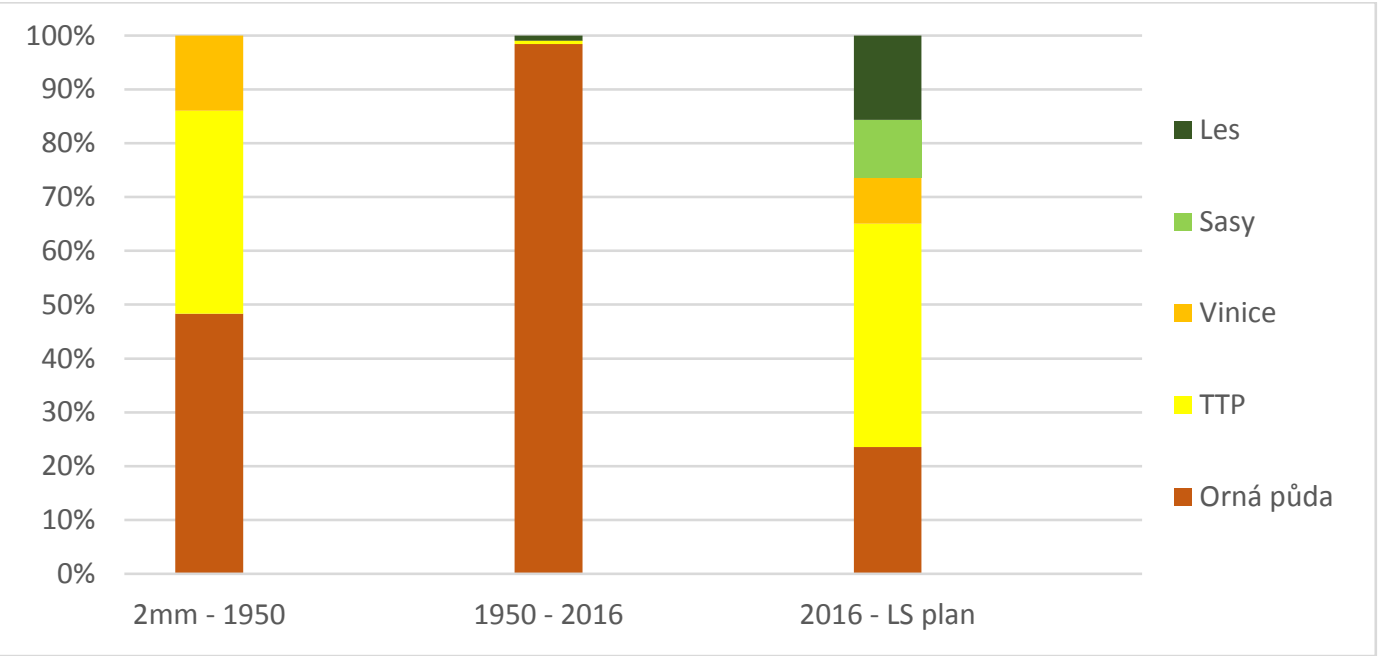

Fig 11. Graphical representation of the percentage of sealed types of land.

The results show that 9.53 ha of soil was sealed since the time of the second military mapping (1836-1852) to 1950, whilst the sealing of arable land prevails. Between 1950 and present, the total of 19.35 ha (again mostly arable land) were sealed. According to the landscape plan, a further approx. 10 ha should be taken for the purposes of developing residential area from arable land, orchards and forests.

Assessing the loss of acreage of individual ESEU, it was found that it is most frequently the high quality chernozem, soil rich in humus, (ESEU code $0.01 .00,0.06 .00,0.08 .50$ ) (Table 13 and Figure 12) that is the most lost, taken to develop residential areas.

Description of ESEU in Dolní Věstonice cadastre:

0.01 .00 - Flat and moderately sloped Haplic Chernozems, soils with thick humus horizon, with crumb to granular structure, developed from loose carbonate substrates, deep soils

0.06.00 - Vertic Chernozems, heavy to highly heavy, on heavy bedrock

0.08.50 - Washed-off (eroded) Haplic Chernozems with cultivated substrate, in sloped terrain 
0.20.11 - Vertic Cambisols on very heavy substrates (clays, flysches), with low permeability, skeleton-less, deep, in places slightly gleyed, moderately sloped

0.40 .77 - Strongly sloped terrain, medium heavy to light texture, with varying skeletability, medium deep to deep, moisture dependent on climate and exposure

0.56 .00 - Flat and moderately sloped Fluvisoils, deep soil profile, slightly dry climatic region

99 - no agricultural land

Tab 13. Sealing of individual ESEU and total price of degraded soil by the decree no. 441/2013 - Dolní Věstonice.

\begin{tabular}{|c|c|c|c|c|c|c|c|c|c|c|}
\hline \multirow[b]{2}{*}{ ESEU } & \multirow{2}{*}{$\begin{array}{l}\text { Price of } \\
\text { ESEU } \\
\left(€ / \mathrm{m}^{2}\right)\end{array}$} & \multicolumn{3}{|c|}{$2 \mathrm{MM}-1950$} & \multicolumn{3}{|c|}{ 1950-2016 } & \multicolumn{3}{|c|}{ 2016-LS plan } \\
\hline & & ha & $\%$ & $\begin{array}{c}\text { Total } \\
\text { price }(€)\end{array}$ & ha & $\%$ & $\begin{array}{c}\text { Total } \\
\text { price }(€)\end{array}$ & ha & $\%$ & $\begin{array}{c}\text { Total } \\
\text { price }(€)\end{array}$ \\
\hline 0.01 .00 & 0.62 & 0 & 0 & 0 & 0.50 & 2.57 & 3,100 & 0.05 & 0.54 & 310 \\
\hline 0.06 .00 & 0.43 & 1.67 & 17.52 & 7,181 & 2.69 & 13.89 & 11,567 & 2.28 & 22.98 & 9,804 \\
\hline 0.08 .50 & 0.37 & 2.89 & 30.33 & 10,693 & 7.93 & 41 & 29,341 & 2.38 & 24.1 & 8,806 \\
\hline 0.20 .11 & 0.27 & 2.32 & 24.34 & 6,264 & 4.74 & 24.51 & 12,798 & 4.98 & 50.49 & 13,446 \\
\hline 0.40 .77 & 0.04 & 0 & 0 & 0 & 0.20 & 1.06 & 80 & 0.002 & 0.02 & 0.8 \\
\hline 0.56 .00 & 0.55 & 0 & 0 & 0 & 1.69 & 8.71 & 9,295 & 0.19 & 1.87 & 1,045 \\
\hline 99 & 0 & 2.65 & 27.81 & 0 & 1.6 & 8.26 & 0 & 0 & 0 & 0 \\
\hline Total & & 9.53 & 100 & 24,138 & 19.35 & 100 & 66,181 & 9.88 & 100 & $33,411.8$ \\
\hline
\end{tabular}

The total surface of the sealed soil between $2^{\text {nd }}$ military mapping and present (2016) is 28.88 ha. The total soil price of this area is 90,319 EUR. This clearly shows significant effects of soil sealing process on the land price.

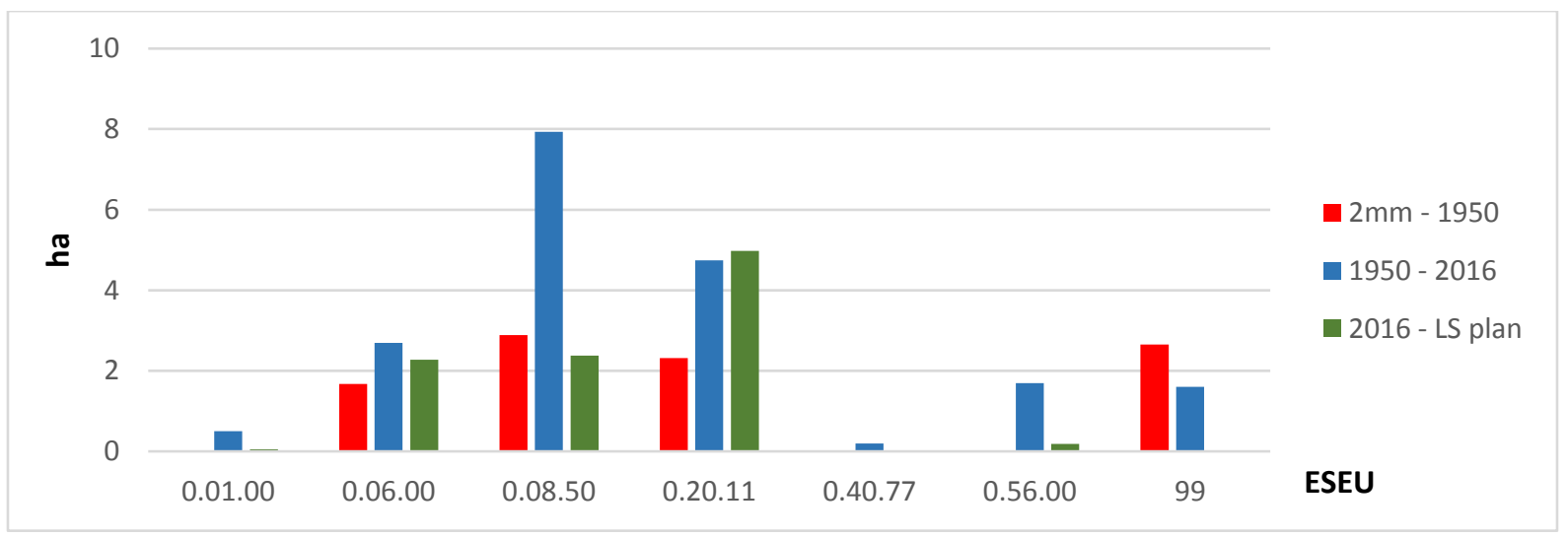

Fig 12. Graphical representation of sealed Evaluated Soil-Ecological Units.

\section{Conclusion}

The amount of land that was used for farming or forest management dropped considerably in the presented locations in individual time horizons. In the case of Dolní Věstonice there was a reduction in soil due to build-up and due to the construction of water reservoirs. The built-up area tripled over the period under review. The construction of the water reservoirs "Nové Mlýny" changed the landscape character. The extensive forests and meadows were flooded. Water elements can be utilised for economic purposes (fish or water fowl breeding). The area gained a different character, character of the landscape has changed considerably, growing tourism enabled municipal progress and next sealing of agricultural land for construction. In the case of Modrice however, the sealing were irreversible, built-up areas changed the hydrology of the area in a negative direction (impenetrable areas). 
Agricultural soil sealing is a world-wide problem. For a long time, the drop in agricultural soil was not perceived particularly negatively, given the agricultural production, since due to breeding new varieties and the use of industrial fertilisers and pesticides, agricultural yields kept rising. Gradual degradation of the soil fund associated with decreasing biodiversity and the environmental balance in agricultural landscape went hand in hand with this trend. At present, the negative impacts of intensive farming on ecosystems are increasingly emphasised while promoting organic agriculture. This manner of farming puts increased pressure on the coverage of cultivated land because the yields of agricultural crops without using chemicals cannot attain the same values as intensive farming. The agricultural policy of the EU also plays a significant role in the use and protection of the soil fund. In the years of its functioning, State agricultural policy urged farmers to use modern mechanisation and new approaches, including chemical fertilisers and plant protection preparations. This policy was efficient and productivity grew. The task farmers face is to produce as much foodstuff as possible from a diminishing number of sources (the area of agricultural land is decreasing). At present, there is over-production in the EU but the threat of climatic extremes, including agricultural drought that may in future adversely affect our bestyielding locations, will probably cause a drop in strategic commodities production. The intensity of agricultural soil fund sealing and the devastation of agricultural soil presented in the article is another negative factor that must be taken into consideration when planning agricultural policy. The study in model areas Dolní Věstonice and Modrice confirmed that the soil protection law No. 334/1992 Coll. is not respected in the Czech Republic. The lands with the best soils (Cheznozems) in 1st and 2nd class protection (highest priority of soil protection) are used for building. The Landscape plans calculate with the areas of the best soils for building purposes in the future. By the example of the two cadastres, located in the most fertile area of Moravian region, there was performed not only how many hectares of agricultural land were changed to other use, but also the loss of highest quality soils was performed, expressed by the soil price. In the cadastral area of Modřice, 382 ha of agricultural land (arable land, grasslands, orchards, and vineyards) have been built since the mid-19th century. The area is located near the city of Brno. The location is characterized by rapid development in recent years (housing, industrial zones, infrastructure). In the cadastral area of Dolní Věstonice the area of the built-up area increased by 29 ha. This is a rural area. The small village of Dolni Věstonice is growing more slowly. The main importance in this area was the construction of the "Nové Mlýny" reservoirs, which were built mainly on forest lands and permanent grasslands. As a result of the growing built-up area and infrastructure (at today's agricultural land prices), at least 2,071,399 EUR was lost in Modřice and 90,319 EUR in Dolní Věstonice. These prices do not include the production potential of lost agricultural land. The production potential of the Czech agriculture presents about 3.5 millions ha of the agricultural land. About $50 \%$ of this land is located in the less favourable areas. The amount of soil loss by the appropriation presents about 15 ha per year, previously in the fertile areas. It seems to be the negative and ongoing trend. The aim of the presented results was to demonstrate the temporary development of the soil appropriation and the radical changes in the land use in analysed localities.

\section{Acknowledgement}

This study was supported by the Internal Grant Agency, Faculty of AgriSciences, MENDELU No. AF-IGA-IP-04/2017 'Degradation of agricultural land resources in selected areas in the South Moravian region' and research project MZE RO0217.

\section{References}

[1] Antrop, M. (1998). Landscape change: Plan or chaos? Landscape and Urban Planning, 41(3-4): 155-161. DOI: 10.1016/S0169-2046(98)00068-1.

[2] Gerland, P., Raftery, A. E., Ševčíková, H., Li, N., Gu, D., Spoorenberg, T., Alkema, L., Fosdick, B. K., Chunn, J., Lalic, N., Bay, G., Buettner, T., Heilig, G. K. \& Wilmoth, J. (2014). World population stabilization unlikely this century. Science 346(6206), 234-237. DOI: $10.1126 /$ science. 1257469 . 
[3] van der Heijde, P. (2012). New urban centres in the Netherlands. Tijdschrift voor Economische en Sociale Geografie 103(3), 362-373. DOI: 10.1111/j.14679663.2012.00725.x.

[4] Hersperger, A. M., Buergi, M. (2009). Going beyond landscape change description: Quantifying the importance of driving forces of landscape change in a Central Europe case study. Land Use Policy 26(3), 640-648. DOI: 10.1016/j.landusepol.2008.08.015.

[5] Chen, J. (2007). Rapid urbanization in China: A real challenge to soil protection and food security. CATENA 69(1), 1-15. DOI: 10.1016/j.catena.2006.04.019.

[6] Janků, J., Jakšík, O., Kozák, J. \& Marhoul, A. M. (2016). Estimation of land loss in the Czech Republic in the near future. Soil \& Water Research 11(3), 155-162. DOI: 10.17221/40/2016SWR.

[7] Janků, J., Sekáč, P., Baráková, J. \& Kozák, J. (2016). Land use analysis in terms of farmland protection in the Czech Republic. Soil \& Water Research 11(1), 20-28. DOI: 10.17221/163/2015-SWR.

[8] Jeleček, L., Burda, T. \& Chromý, P. (1999). Historická geografie a výzkum vývoje struktury půdního fondu Česka od poloviny 19. století. Historická geografie 30, 261-270.

[9] Kupka, J. (2010). Krajiny kulturní a historické. Vliv hodnot kulturní a historické charakteristiky na krajinný ráz naši krajiny. Praha: České vysoké učení technické.

[10] Lambin, E. F., Turner, B. L., Geist, H. J., Agbola, S. B., Angelsen, A., Bruce, J. W., Coomes, O. T., Dirzo, R., Fischer, G., Folke, C., George, P. S., Homewood, K., Imbernon, J., Leemans, R., Li, X., Moran, E. F., Mortimore, M., Ramakrishnan, P. S., Richards, John F., Skånes, H., Steffen, W., Stone, G. D., Svedin, U., Veldkamp, T. A., Vogel, C. \& Xu, J. (2001). The causes of land-use and land-cover change: moving beyond the myths. Global Environmental Change 11(4), 261-269. DOI: 10.1016/S0959-3780(01)00007-3.

[11] Lipský, Z. (2000). Sledování změn v kulturní krajině: Učebnicový text pro cvičení z předmětu Krajinná ekologie. Kostelec nad Černými lesy: Lesnická práce.

[12] Lokoč, R. \& Lokočová, M. (2010). Vývoj krajiny v České republice. Brno: Lipka.

[13] Mašát, K. a kol. (2002). Metodika vymezování a mapování bonitovaných půdně ekologických jednotek. Praha: VúMOP, v.v.i.

[14] Montgomery, M. R. (2008). The urban transformation of the developing world. Science 319(5864): 761-764. DOI: 10.1126/science.1153012.

[15] Podhrázská, J., Karásek, P. et al. (2014). Systém analýzy území a návrh opatření k ochraně půdy a vody $v$ krajině - podklad pro území plánování a pozemkové úpravy. [methodological instruction]. Brno: VÚMOP.

[16] Podhrázská, J., Kučera, J., Karásek, P., Konečná, J. (2015). Land degradation by erosion and its economic consequences for the region of Jihomoravský (Czech Republic). Soil and Water Research 10(2), 105-113. DOI: 10.17221/143/2014-SWR.10.xxx.

[17] Piorr, A., Ravetz, J. \& Tosics, I. (2011). Peri-urbanisation in Europe: Towards a European policy to sustain urban-rural futures. Københaven: University of Copenhagen.

[18] Seto, K. C., Güneralp, B. \& Hutyra, L. R. (2012). Global forecasts of urban expansion to 2030 and direct impacts on biodiversity and carbon pools. Proceedings of the National Academy of Sciences of the United States of America 109(40), 16083-16088. DOI: 10.1073/pnas.1211658109

[19] Spilková, J. \& Šefrna, L. (2010). Uncoordinated new retail development and its impact on land use and soils: A pilot study on the urban fringe of Prague, Czech Republic. Landscape and Urban Planning 94(2), 141-148. DOI: 10.1016/j.landurbplan.2009.09.001. 
[20] AGRARHEUTE, EU will stärker gegen Bodenversiegelung vorgehen. in: Agrarheute [online]. 2011 [cit. 2017-04-25]. Available: http://www.agrarheute.com/bodenversiegelungdeutschland.

[21] DECREE No. 441/2013 Sb. of December 17, 2013, for execution of the Act on Property Valuation (Valuation Decree). Czech Republic (in Czech).

[22] EUROPEAN ENVIRONMENT AGENCY, 2006: Urban Sprawl in Europe - The Ignored Challenge. EEA Report No 10/2006.

[23] EUROPEAN ENVIRONMENT AGENCY, 2016: Urban Sprawl in Europe. Joint EEA-FOEN report.

[24] FAO, 2011: The state of the world's land and water resources for food and agriculture - managing systems at risk, Summary Report, Food and Agriculture Organization of the United Nations, Rome.

[25] Charvát, H. 2010: MŽP chce úbytek zemědělské půdy zastavit vyššími poplatky. ekolist [online]. 2010 [cit. 2017-03-20]. ISSN 1802-9019. available: http://ekolist.cz/cz/zpravodajstvi/zpravy/mzp-chce-ubytek-zemedelske-pudy-zastavitvyssimi-poplatky.

[26] SCIENCE FOR ENVIRONMENT POLICY. 2012: Soil Sealing - In-depth report. European Comission, Directorate-General Environment.

[27] UNFPA, 2007: State of world population 2007: Unleashing the potential of urban growth. United Nations Population Fund.

[28] UN, 2006: World urbanization prospects: The 2005 revision. United Nations Department of Economic and Social Affairs, Population Division, New York, NY.

[29] UN, 2012: World urbanization prospects: The 2011 revision - Highlights. United Nations Department of Economic and Social Affairs, Population Division, New York, NY.

[30] UN, 2014: World urbanization prospects: The 2014 revision. United Nations Department of Economic and Social Affairs, Population Division, New York, NY. 